(c) American Dairy Science Association, 2004.

\title{
The Effect of Protein Intake on Performance of Cows in Hot Environmental Temperatures
}

\author{
A. Arieli, ${ }^{1}$ G. Adin, ${ }^{2}$ and I. Bruckental ${ }^{3}$ \\ ${ }^{1}$ The Hebrew University of Jerusalem, Faculty of Agricultural, Food, and Environmental Quality Sciences, Rehovot, Israel \\ ${ }^{2}$ The Extension Service, Ministry of Agriculture, Bet-Dagan, Israel \\ ${ }^{3}$ Institute of Animal Science, Agricultural Research Organization, The Volcani Center, Bet Dagan, Israel
}

\section{ABSTRACT}

Two trials were conducted with cows in commercial herds during midlactation to evaluate the effect of dietary crude protein $(\mathrm{CP})$ concentration on the production, composition, and efficiency of milk production under hot ambient conditions. Cows were group-fed in trial 1, which was conducted in two herds, and were fed individually in trial 2 . The respective average ambient temperature, relative humidity, and temperature-humidity index (THI) were $31^{\circ} \mathrm{C}, 45 \%$, and 78 in trial 1 and $27^{\circ} \mathrm{C}, 70 \%$, and 76 in trial 2 . Cows were cooled by forced evaporative means six times daily in trial 1 and three times daily in trial 2. Dietary CP was 15.3 or $17.3 \%$ of dry matter (DM) in trial 1 and 15.1 or $16.7 \%$ of DM in trial 2. The respective ratios of rumen-degradable organic matter (RDOM) to rumen-degradable protein were 5.3 and 4.8 for the low CP (LP) and high CP (HP) diets. Average DM intake, milk yield, and milk fat and protein concentrations were 22 and $23 \mathrm{~kg} / \mathrm{d}, 34$ and $35 \mathrm{~kg} / \mathrm{d}, 3.1$ and $3.4 \%$, and 3.2 and $3.1 \%$ in trials 1 and 2, respectively, and were similar among diets in both trials. The resultant calculated milk protein efficiency ratio and overall CP efficiency were 0.31 and 0.32 for the LP diets and 0.28 and 0.29 for the HP diets. In cows fed the LP diet, diet rumen ammonia was lower in trial 1 , and milk urea $\mathrm{N}$ was lower in trial 2 . The BW change was higher in trial 1 , and tended to be higher in trial 2, with the LP diets. Changes in body condition score in trials 1 and 2 tended to be higher with the LP diets. It was concluded that a dietary CP content of $15.3 \%$ is adequate to maintain production in heat-exposed dairy cows producing $35 \mathrm{~kg}$ of milk/d, provided that the forced evaporative cooling and the ratio of RDOM to rumen-degradable protein is appropriate

(Key words: heat stress, dietary crude protein, milk protein efficiency)

Received June 20, 2003.

Accepted November 11, 2003.

Corresponding author: A. Arieli; e-mail: arieli@agri.huji.ac.il.
Abbreviation key: $\mathbf{H P}=$ high CP, INDF = indigestible NDF, $\mathbf{L P}=$ low CP, RDOM = rumen-degradable OM, RDP = rumen-degradable CP, $\mathbf{T H I}=$ temperature-humidity index.

\section{INTRODUCTION}

In animals exposed to high environmental temperatures, DMI normally decreases, and, consequently, milk yield is also reduced (NRC, 1981). Analysis of environmental effects on dairy cow yield under Mediterranean climate (range of average monthly maximum $=18$ to $32^{\circ} \mathrm{C}$ ) revealed that daily yields of milk and milk protein were reduced by 0.38 and $0.01 \mathrm{~kg} /{ }^{\circ} \mathrm{C}$ of ambient temperature increase, respectively (Barash et al., 2001). To counteract the reduction in nutrient intake and to sustain productivity, an increased nutrient concentration in the diet might be needed (West, 1999). When dietary modifications for heat-stressed cows are being considered, care should also be taken to lower the increment of heat associated with food ingestion. Improved milk yields of heat-stressed cows as a result of increased concentrations of dietary fat (Knapp and Grummer, 1991; Skaar et al., 1989) and reduced fiber concentration (Cummins, 1992) are well documented and may be explained by a reduction in metabolic heat production under high environmental temperatures.

On the other hand, responses, in terms of milk yield and efficiency, of heat-stressed cows to modifications in dietary protein content or quality are less clear. Hassan and Roussel (1975) increased the dietary protein content of heat-exposed (daily maximum $=31^{\circ} \mathrm{C}$ ) cows from 14.3 to $20.8 \%$ and observed increases of 11 and $4.3 \%$ in DMI and in FCM yield, respectively. Although milk protein concentration was not reported in that trial, in light of the difference of $62 \%$ in CP intake between groups, it is very likely that the increase in milk yield was associated with a concomitant reduction in milk protein production efficiency.

Higginbotham et al. (1989a) investigated the effect of CP level (18\% vs. 15\%) on milk yield of cows during mid lactation; the cows were maintained under mild heat conditions (daily maximum $=27^{\circ} \mathrm{C}$ ). Milk yield 
was not affected by percentage of dietary protein, but milk protein efficiency was higher for the low protein diet. Those researchers (Higginbotham et al., 1989b) compared the effects of protein level (18.5\% vs. 16\%) and rumen CP degradability (RDP; $65 \%$ vs. $59 \%$ of $\mathrm{CP}$ ) on productivity of cows during mid lactation; the cows were housed under severe heat stress (daily maximum $=35^{\circ} \mathrm{C}$ ). Milk yield and composition were similar among treatments. Although DMI was higher with the low protein diet, data suggested that milk protein efficiency tends to increase with the lower dietary protein concentration.

Taylor et al. (1991) performed a trial in summer (daily maximum $=36^{\circ} \mathrm{C}$ ) with cows during mid lactation fed an $18 \% \mathrm{CP}$ diet consisting of 61 or $47 \% \mathrm{RDP}$ of $\mathrm{CP}$. Milk yield, milk protein yield, and BW were higher in the low RDP group. The results suggested that a low RDP diet could improve milk yield during heat stress.

In early lactating cows calving in a hot environment (average $=27^{\circ} \mathrm{C}$ ), reducing the RDP from 65 to $54 \%$ of $\mathrm{CP}$ resulted in more BW loss with little influence on the efficiency of utilization of energy for milk yield (Nianogo et al., 1991).

From these reports, it appears that under high environmental temperatures, reducing the supply of dietary CP or RDP might improve efficiency of milk yield, efficiency of milk protein production, or both. It has been suggested that milk yield is affected adversely by excessive intake of RDP and that energy expenditure for urea synthesis might be partially responsible for the depressed milk yield of cows fed with surplus CP (Higginbotham et al., 1989b).

It is worth noting that the level of RDP used in some of the aforementioned trials (54\%, [Nianogo et al., 1991] and 47\% [Taylor et al., 1991]) was considerably lower than the recommended RDP concentration of 61 to $64 \%$ for cows not under heat stress (NRC, 2001). A shortage of RDP may limit microbial growth (Dijkstra et al., 1998) and may lead to a reduced supply of metabolizable protein and milk protein (Rodriguez et al., 1997). In the current study, the effect of reducing CP intake on milk protein production and efficiency of milk protein production was examined in cows maintained in hot environmental temperatures and supplied with the recommended RDP concentration.

\section{MATERIALS AND METHODS}

\section{Cow Management and Diets}

Two trials were conducted in commercial herds to assess the productive responses of heat-exposed dairy cows to dietary protein level. trial 1 was conducted in two herds and cows were group-fed. Cows were individually fed in trial 2 . Trial 1A was performed from July to September 1996 (for 90 d) in Kibbutz Kalia (altitude = $-365 \mathrm{~m}$ ); trial 1B was performed in Kibbutz Ashdot Yaakov (altitude $=-220 \mathrm{~m}$ ) from May to July 1997 (for $80 \mathrm{~d}$ ). Trial 2 was performed in the Volcani Center in Bet Dagan (altitude $=30 \mathrm{~m}$ ) from May to July 2002 (for $80 \mathrm{~d}$ ). Climatic conditions during the experimental periods are described in Table 1.

One hundred, 120, and 42 multiparous Israeli Holstein-Friesian cows (parity $=2.5 \pm 1.1,3.8 \pm 1.6$, and $3.0 \pm 1.3$ ) were used in trials $1 \mathrm{~A}, 1 \mathrm{~B}$, and 2 , respectively. In each trial, cows were evenly assigned to the high CP (HP) or low CP (LP) diets according to initial milk yield, lactation number, and DIM. Cows were kept in an open, shaded barn adjoining an unshaded yard. The experimental groups were kept under similar conditions, including space, roof area, shade ( $10 \mathrm{~m}^{2}$ per cow), and water supply. In all trials, animals were kept in closed groups, yet in trial $1 \mathrm{~A}$ and $1 \mathrm{~B}$, because of incidences of mastitis and lameness, 3 and 4 cows, respectively, from each treatment were removed.

Average milk yield at the beginning of trial $1 \mathrm{~A}$ was $32.9 \pm 0.4 \mathrm{~kg} / \mathrm{d}$, DIM was $199 \pm 4.5 \mathrm{~d}$, and BW was 605 $\pm 10 \mathrm{~kg}$. Respective values were $43.4 \pm 1.0 \mathrm{~kg} / \mathrm{d}, 130 \pm$ $6 \mathrm{~d}$, and $608 \pm 5 \mathrm{~kg}$ in trial $1 \mathrm{~B}$ and $40.8 \pm 0.7 \mathrm{~kg} / \mathrm{d}, 134$ $\pm 10 \mathrm{~d}$, and $607 \pm 7 \mathrm{~kg}$ in trial 2 .

Cows were routinely cooled by forced evaporative means. In all herds, three showers per day were administered just before milking; in trial 1 , the cows had an additional three showers per day between milkings. The showers took place in the waiting yard (holding area) prior to milking. Each cooling period consisted of 7 to 8 cycles lasting for $30 \mathrm{~s}$ of showering followed by $270 \mathrm{~s}$ of forced ventilation. In trial 1 , cows were tied in the stalls 4 times/d for 40 min where water vapor was applied with sprinklers. On all farms, forced ventilation was provided by an array of fans along a shaded feeding trough. The cooling schedule at the feeding trough was similar to that in the waiting yard.

In trial 1A, cows were weighed after the morning milking for 2 consecutive $d$ at the beginning, middle, and end of the experiment. In trial 1B, the BCS (Wildman et al., 1982) was evaluated every week. In trial 2 , cows were weighed after every milking, and the BCS was evaluated weekly.

Feed was provided at $0430 \mathrm{~h}$ in trial $1 \mathrm{~A}$, at 0330 and $0730 \mathrm{~h}$ in trial $1 \mathrm{~B}$, and at $1000 \mathrm{~h}$ in trial 2. Feed was administered using a commercial mixer wagon (RMH; Lachish Industries, Industrial Zone, Sderot, Israel) equipped with a weight controller. In trial 1 , feed at the feeding trough was shoveled toward the animals at least 7 times/d. Orts were collected daily and weighed in the feeding mixer wagon. In trial 2 , daily DM offered to each cow and feed refused were recorded by a realtime control system for individual dairy cow feed intake 
Table 1. Ambient temperature and humidity.

\begin{tabular}{|c|c|c|c|c|c|c|}
\hline & \multicolumn{2}{|c|}{ Trial 1A } & \multicolumn{2}{|c|}{ Trial 1B } & \multicolumn{2}{|c|}{ Trial 2} \\
\hline & $\mathrm{X}$ & $\mathrm{SD}$ & $\mathrm{X}$ & $\mathrm{SD}$ & $\mathrm{X}$ & $\mathrm{SD}$ \\
\hline \multicolumn{7}{|l|}{ Temperature $(\mathrm{T}),{ }^{\circ} \mathrm{C}$} \\
\hline Minimal & 26.5 & 1.5 & 21.0 & 2.6 & 22.2 & 3.0 \\
\hline Maximal & 38.9 & 1.9 & 39.5 & 2.4 & 32.2 & 3.0 \\
\hline Average & 32.7 & 1.5 & 28.7 & 2.3 & 27.2 & 2.6 \\
\hline Days with maximum $>32^{\circ} \mathrm{C}, \%$ & 100 & & 100 & & 55 & \\
\hline Days with maximum $>35^{\circ} \mathrm{C}, \%$ & 100 & & 75 & & 11 & \\
\hline \multicolumn{7}{|l|}{ Humidity (H),\% } \\
\hline Minimal & 30.8 & 2.4 & 29.7 & 4.8 & 50.8 & 9.8 \\
\hline Maximal & 58.6 & 0.8 & 59.3 & 9.5 & 88.3 & 6.0 \\
\hline Average & 44.7 & 1.5 & 44.5 & 7.1 & 69.5 & 6.9 \\
\hline \multicolumn{7}{|l|}{$\mathrm{THI}^{1}$} \\
\hline Minimal & 74.7 & 2.0 & 67.2 & 3.8 & 70.7 & 5.0 \\
\hline Maximal & 85.2 & 1.9 & 82.1 & 2.6 & 80.8 & 3.6 \\
\hline Average & 79.9 & 1.6 & 74.7 & 3.0 & 75.8 & 4.1 \\
\hline Days with $8 \mathrm{~h}>78$ THI, \% & 98 & & 50 & & 50 & \\
\hline Days with 16 h >78 THI, \% & 95 & & 20 & & 33 & \\
\hline
\end{tabular}

${ }^{1} \mathrm{THI}=$ Temperature-humidity index $\left(\right.$ Chambers, 1970) $=\mathrm{T}\left({ }^{\circ} \mathrm{F}\right)-(0.55-0.55 \times \mathrm{H}) \times\left(\mathrm{T}\left[{ }^{\circ} \mathrm{F}\right]-58\right)$.

(Halachmi et al., 1998). Diets were sampled once weekly, and orts were analyzed for DM, CP, and NDF. In both trials, feed was supplied as a TMR for ad libitum intake. Meals were offered to allow $6 \%$ refusals according to the calculated TMR consumed the previous day for each group (trial 1) or cow (trial 2). In both trials, samples of diets and refusals were taken from the mixer outlet daily, dried, ground, composited on a weekly basis by $\mathrm{DM}$ weight, and stored at $-20^{\circ} \mathrm{C}$ until analysis.

Cows were milked at 0300,1100 , and $1900 \mathrm{~h}$ in trial $1 \mathrm{~A}$; at 0400,1200 , and $2000 \mathrm{~h}$ in trial $1 \mathrm{~B}$; and at 0600 , 1400 , and $2000 \mathrm{~h}$ in trial 2. Milk yield was recorded daily by an automatic meter (Afimilk, Zaham Afikim, Israel). Milk samples were taken every $14 \mathrm{~d}$ during the experimental periods, from each daily milking time $(3 \times)$, and composited by milk volume. The composited milk samples were analyzed for concentrations of fat, protein, lactose, and urea (in trial 2 only) by mid-infrared spectrometry (Milkoscan FT 6000; Foss Electric, Denmark) at the Israeli Cattle Breeders Association (Milk Recording Laboratory, Industrial Area, Caesarea, Israel).

Diets contained wheat silage and alfalfa hay as the forage sources in trial 1A, corn silage and alfalfa hay as the forage sources in trial $1 \mathrm{~B}$, and corn silage and wheat silage as the main forage sources in trial 2 (Table 2). Complementary ingredients were calculated using a least-cost linear program (Gavish, Givat-Brener, Israel) to supply target compositions for LP and HP diets: 15.0 and $16.9 \% \mathrm{CP}$ in trial $1 \mathrm{~A}, 15.7$ and $17.4 \% \mathrm{CP}$ in trial $1 \mathrm{~B}$, and 15.1 and $16.7 \% \mathrm{CP}$ in trial 2 (Table 3 ). The level of RUP was $35 \%$ of CP in both trials. Diets contained $1.7 \mathrm{Mcal}$ of $\mathrm{NE}_{\mathrm{L}} / \mathrm{kg}$ of $\mathrm{DM}$ and $35 \% \mathrm{NDF}$; forage $\mathrm{NDF}$ constituted $51 \%$ of total dietary NDF.
Samples of dietary ingredients were incubated in the rumen using the standard in situ method described subsequently. The in situ effective degradability values of $\mathrm{CP}$ and $\mathrm{OM}$ were used in linear programming software (Gavish) to compose the experimental diets. Assuming ingredient additivity of ruminal degradation, the resultant ratios of rumen-degradable OM (RDOM) to RDP in both trials were 4.8 in HP diets and 5.3 in LP diets.

In trial 2 , total tract nutrient digestibility was evaluated during wk 4 and 9 using indigestible NDF (INDF) as an internal marker (Lippke et al., 1986). Feed and feces were sampled during a 3-d period, as follows: the ration was offered to each cow, and the refusals were sampled. Fecal grab samples were taken 3 times/d at 0700, 1200, and $1900 \mathrm{~h}$. All ration refusals and fecal samples of each cow were pooled, dried at $55^{\circ} \mathrm{C}$, ground to pass a $2-\mathrm{mm}$ screen, and stored at $-20^{\circ} \mathrm{C}$.

During wk 7, rumen fluid and blood were withdrawn from 30 to 35 cows per treatment in trial 1 . The samples were taken $1 \mathrm{~h}$ before the morning meal and $3 \mathrm{~h}$ postfeeding. Rumen liquor was sampled through a stomach tube, and blood was taken simultaneously by venipuncture of the tail vein. In trial 2, blood was withdrawn from all cows at wk 4 and 8 of the experimental period, the samples were taken $1 \mathrm{~h}$ before the morning meal. Ruminal samples and heparinized blood were immediately placed on ice. Samples were centrifuged (1000 or $5000 \times g$ for blood and rumen specimens, respectively), and plasma and ruminal supernatants were separated and frozen at $-20^{\circ} \mathrm{C}$ until analysis.

Minimum and maximum ambient temperatures were measured in the cow barn using minimum-maximum thermometers (Brannan TFA3100; Cleator Moor, UK). Calculations of temperature-humidity index (THI) 
Table 2. Feed ingredients (\% of DM).

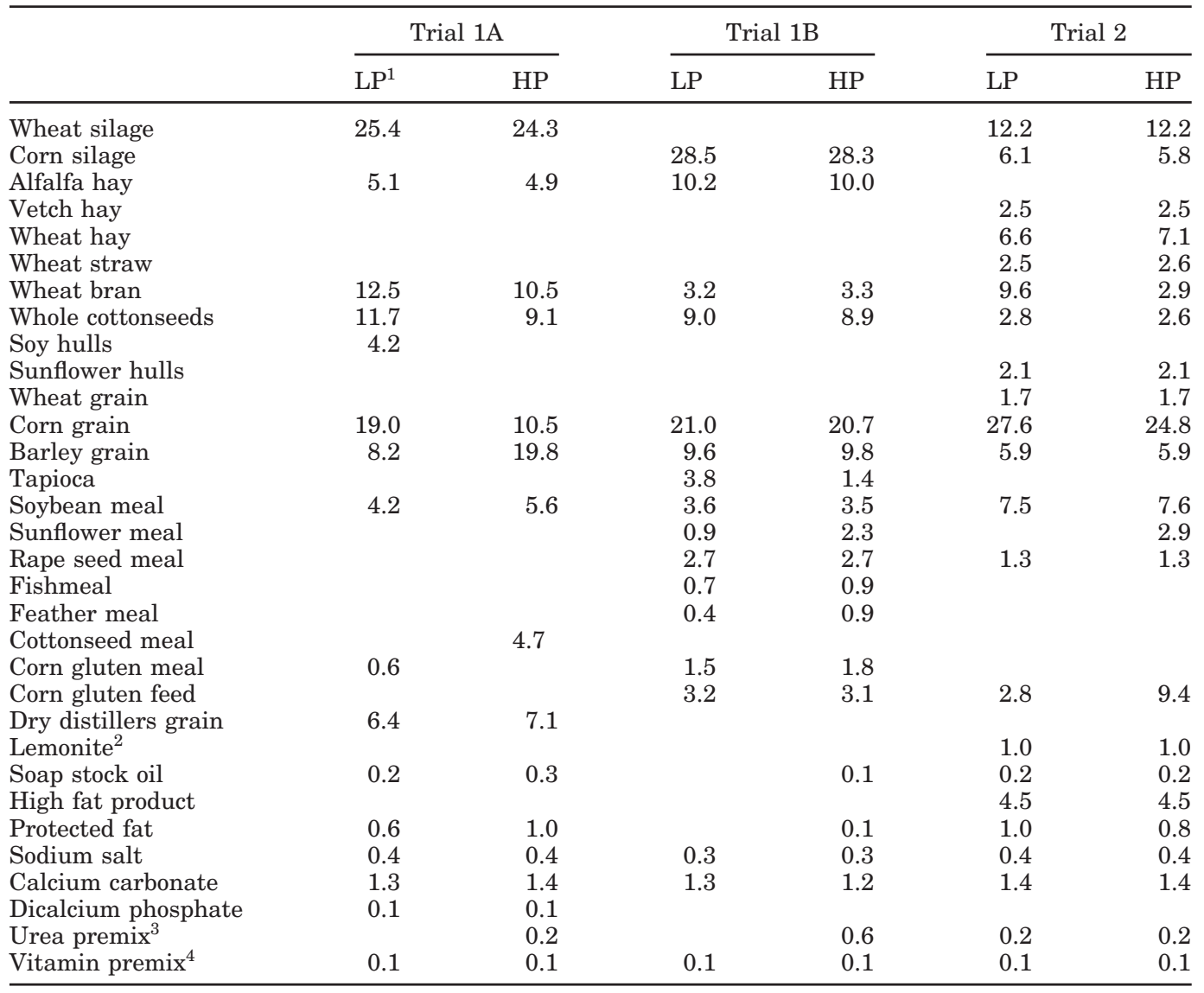

${ }^{1} \mathrm{LP}=$ Low $\mathrm{CP} ; \mathrm{HP}=$ high $\mathrm{CP}$.

${ }^{2}$ By-product of the citric acid manufacturing by the fermentation industry.

${ }^{3}$ Containing $58 \%$ sorghum grain.

${ }^{4}$ Each kilogram of vitamins and mineral mix contains1.2 $\mathrm{g}$ of vitamin A, $10 \mathrm{mg}$ of vitamin D, $2.01 \mathrm{~g}$ of vitamin $\mathrm{E}, 12 \mathrm{mg}$ of $\mathrm{Mn}, 12 \mathrm{mg}$ of $\mathrm{Zn}, 4 \mathrm{mg}$ of Fe, $240 \mathrm{mg}$ of $\mathrm{I}_{2}, 40 \mathrm{mg}$ of Co, $100 \mathrm{mg}$ of Se, $800 \mathrm{mg}$ of $\mathrm{Cu}$, $1.4 \mathrm{mg}$ of $\left(\mathrm{NH}_{3}\right)_{2} \mathrm{SO}_{4}, 1 \mathrm{mg}$ of $\mathrm{MgSO}_{4}, 180 \mathrm{mg}$ of $\mathrm{Ca}, 90 \mathrm{mg}$ of $\mathrm{P}$, and $90 \mathrm{mg}$ of $\mathrm{NaCl}$.

Table 3. Diet composition (\% of DM).

\begin{tabular}{|c|c|c|c|c|c|c|}
\hline & \multicolumn{2}{|c|}{ Trial 1A } & \multicolumn{2}{|c|}{ Trial 1B } & \multicolumn{2}{|c|}{ Trial 2} \\
\hline & $\mathrm{LP}^{1}$ & HP & LP & $\mathrm{HP}$ & LP & HP \\
\hline $\mathrm{NE}_{\mathrm{L}}, \mathrm{Mcal} / \mathrm{kg}$ & 1.76 & 1.77 & 1.72 & 1.72 & 1.71 & 1.72 \\
\hline $\mathrm{NDF}$ & 38.6 & 37.0 & 31.3 & 31.5 & 32.0 & 32.0 \\
\hline $\mathrm{FNDF}^{2} \%$ of NDF & 43.6 & 43.7 & 55.9 & 55.4 & 53.6 & 53.9 \\
\hline $\mathrm{CP}$ & 15.0 & 16.9 & 15.7 & 17.4 & 15.1 & 16.7 \\
\hline $\mathrm{RUP},{ }^{3} \%$ of $\mathrm{CP}$ & 35.7 & 33.4 & 34.5 & 34.3 & 35.8 & 35.8 \\
\hline $\mathrm{OM}$ & 92.9 & 92.5 & 93.5 & 93.6 & 93.0 & 93.0 \\
\hline $\mathrm{RDOM}^{4}$ & 51.4 & 53.0 & 54.0 & 52.8 & 50.8 & 53.6 \\
\hline RDOM:RDCP & 5.2 & 4.7 & 5.3 & 4.6 & 5.3 & 5.0 \\
\hline $\mathrm{NFC}^{5}$ & 33.7 & 33.2 & 42.7 & 40.6 & 40.7 & 39.2 \\
\hline Fat & 5.6 & 5.5 & 3.8 & 4.1 & 5.3 & 5.1 \\
\hline
\end{tabular}

${ }^{1} \mathrm{LP}=$ Low $\mathrm{CP} ; \mathrm{HP}=$ high $\mathrm{CP}$.

${ }^{2}$ Forage NDF

${ }^{3}$ Calculated from in situ measurement.

${ }^{4} \mathrm{RDOM}=$ rumen degradable OM; calculated from in situ measurement.

${ }^{5} \mathrm{NFC}=$ nonfibrous carbohydrate $=100-(\mathrm{ash}+\mathrm{CP}+\mathrm{NDF}+$ fat $)$. 
(Chambers, 1970) were based on ambient temperatures and relative humidity records gathered by the Israeli Meteorological Service (Ministry of Transportation, Bet Dagan, Israel). Recording sites were located within 3 $\mathrm{km}$ of Ashdot Yaakov (trial 1B) and the Volcani Center (trial 2) barns and within $6 \mathrm{~km}$ of the Kalia (Trial 1A) barn. In trial $1 \mathrm{~A}$ and trial 2 , rectal temperature was measured every month in at least 20 cows per group, 3 to 4 times during the measuring day, by digital thermometers. These measurements were conducted to assess whether the cows were subjected to heat stress. The measurements were undertaken while cows were maintained in a shed at least 120 min past the last shower.

\section{In Situ Measurements}

For in situ incubations of feeds, polyester bags were suspended in the rumen in four replicates in large nets containing weights for each incubation time. Two dairy cows in mid lactation with semi-permanent cannulas in the rumen were used. Cows were maintained on a standard diet (35:65 roughage to concentrate ratio, $16.5 \% \mathrm{CP}, 35 \% \mathrm{NDF}$, and 1.7 of $\mathrm{NE}_{\mathrm{L}} / \mathrm{kg}$ of $\mathrm{DM}$ ). Dry samples $(5 \mathrm{~g})$, ground to pass through a 2 -mm screen, were weighed into $12-\times 6-\mathrm{cm}$ polyester bags (Lataf Sewing Workshop, Kibbutz Hazor, Israel) with a 45$\mu \mathrm{m}$ mean pore size. To assess the effective degradability of nutrients, bags were introduced serially into the rumen and incubated for $96,48,36,24,12,9,6$, or $3 \mathrm{~h}$. For the INDF measurement, 5-g samples of dry and pooled feces, diets, and refusals were weighted in the polyester bags for $144 \mathrm{~h}$. The rumen-incubated polyester bags were removed together, immediately rinsed with cold tap water, washed in a washing machine with cold water for 45 min without spinning, and dried at $55^{\circ} \mathrm{C}$ for $48 \mathrm{~h}$.

\section{Chemical Analyses}

Feed DM was determined by drying at $105^{\circ} \mathrm{C}$ for 24 h. Diets, refusals, and silage were dried at $55^{\circ} \mathrm{C}$ for 48 h. All dried samples were ground to pass a 2-mm mesh and pooled on a DM basis. The OM analyses were carried out at $600^{\circ} \mathrm{C}$ for $4 \mathrm{~h}$. The $\mathrm{CP}$ content was analyzed by Kjeldahl autoanalyzer (Tecator 1035; Hoganas, Sweden). The content of NDF and ADF was determined by the method of Van Soest et al. (1991) using a Fibretec System M (Tecator 1020 hot extractor). The NDF fraction remaining after $144 \mathrm{~h}$ of rumen incubation was considered as the INDF. Fat was determined by the Folch method (AOAC, 1995). Samples were extracted by chloroform:methanol solution (1:2 wt/vol). Non-fibrous carbohydrate was defined as $100-($ ash $+\mathrm{CP}+\mathrm{NDF}$ + fat).
Rumen ammonia N concentration was determined by the phenol procedure (Chaney and Marbach, 1962). Volatile fatty acids in the ruminal supernatants were assessed by GLC (model 5890; Hewlett Packard, Avondale, PA) on $0.3 \%$ Carbowax $20 M$ with $0.1 \%$ phosphoric acid (Supelco, Bellefonte, PA).

Plasma was analyzed for urea $\mathrm{N}$ (according to Coulomb and Favereau, 1963), glucose (Raichem Kit 85188; Raichem, Columbia, MD), NEFA (NEFA-C kit; Wako, Richmond, VA), BHBA (Sigma kit 310-A; Sigma Chemical Co., St Louis, MO), total protein (Raichem Kit 84086), and albumin (Raichem Kit 85211).

\section{Calculations and Statistical Analyses}

Effective ruminal $\mathrm{OM}$ and $\mathrm{N}$ degradabilities of the different feed fractions were calculated according to Orskov and McDonald (1979) using a fractional passage rate of $6.5 \% / \mathrm{h}$. Efficiency of milk protein production was calculated as the ratio of milk protein yield to $\mathrm{CP}$ intake. Overall CP efficiency was estimated as the ratio of milk protein yield plus body protein accretion to $\mathrm{CP}$ intake. The CP accretion was calculated from BW change and chemical composition of empty BW at various BCS, assuming empty BW $=0.817 \times \mathrm{BW}(\mathrm{NRC}$, 2001).

Statistical analysis was performed using SAS 8.2 (2001). Data on milk yield, milk composition and yield, intake of DM and CP, and efficiency of CP, BW, and BCS were analyzed in a repeated measures model by PROC MIXED, with diet and herd (where relevant) as main effects, cow within diet (and herd) as a random effect, and pre-experimental data and DIM as covariates. For intake of $\mathrm{DM}$ and $\mathrm{CP}$, the experimental unit was "group" in trial 1, and "cow" in trial 2. Comparisons for main effects and their interaction were performed by t-tests on the least squares means. Means of total tract digestibility and ruminal and plasma metabolites were analyzed for significance by Student's t-test. Effects were considered significant at $P<0.05$, unless otherwise stated.

\section{RESULTS AND DISCUSSION}

Effects of weather conditions on DMI and on milk yield of cows are mediated through changes in body temperature (West, 1999). In trial 1A, mean body temperatures $>40.0^{\circ} \mathrm{C}$ were recorded. These high body temperatures were recorded even at $0200 \mathrm{~h}$ (when the maximum daily temperature was $41^{\circ} \mathrm{C}$ ). In trial 2 , the maximal recorded mean body temperature was $39.4^{\circ} \mathrm{C}$, measured at $1200 \mathrm{~h}$ (the respective maximum daily temperature was $33^{\circ} \mathrm{C}$ ). In these trials, body temperature was not affected by dietary treatments. Based on 
Table 4. Effect of dietary protein concentrations on total tract nutrient digestibility (trial 2).

\begin{tabular}{lllll}
\hline & LP $^{1}$ & HP & SEM & $P<$ \\
\hline DM digestibility, \% of DM & 64.5 & 63.1 & 0.4 & 0.027 \\
OM digestibility, \% of OM & 67.8 & 66.4 & 0.4 & 0.022 \\
Digestible OM, \% of DM & 63.0 & 61.7 & 0.4 & 0.025 \\
CP digestibility, \% of CP & 64.4 & 66.2 & 0.7 & 0.053 \\
\hline
\end{tabular}

${ }^{1} \mathrm{LP}=$ Low $\mathrm{CP} ; \mathrm{HP}=$ high $\mathrm{CP}$.

ambient temperature and humidity recordings (Table 1) and on the body temperature recording, it can be concluded that even with the cooling regimen applied in trial $1 \mathrm{~A}$, and to a lesser extent that applied in trials $1 \mathrm{~B}$ and 2 , cows were exposed to heat stress conditions.

\section{Digestibility of Nutrients and DMI}

In trial 2, CP digestibility was 64 and $66 \%$ in LP and HP diets, respectively (Table 4). In cows and sheep that were not heat stressed, CP digestibility was increased by $2 \% / 1 \%$ increase in dietary CP concentration (Cody et al., 1990; Weigel et. al., 1997). The effect of dietary $\mathrm{CP}$ level on total tract CP digestibility appears to be lower under heat stress conditions. The 1.5\% higher $\mathrm{DM}$ and OM digestibility in the LP diet (Table 4) might have been due to differences in the proportions and types of feedstuffs fed between the two experimental diets.

According to NRC (1981) predictions, a reduction of 7 to $8 \%$ in DMI is expected in cows exposed to ambient temperatures of 30 to $35^{\circ} \mathrm{C}$ as compared with cows under thermoneutral conditions. During the experimental period, the overall average DMI for the LP and HP groups were similar (Table 5); in trial 2, the DMI was reduced in both trials by $0.45 \mathrm{~kg} / \mathrm{wk}$. It is worth noting that these daily intakes were similar to NRC (2001) predictions of $20.8,22.8$, and $22.4 \mathrm{~kg}$ of DMI/d for trials $1 \mathrm{~A}, 1 \mathrm{~B}$, and 2 , respectively, for dairy cows that were not heat stressed but that had similar production characteristics. The average DMI in the current study also agrees with the DMI prediction by Fox and Tylutki's model (1998), which takes into account a night cooling effect. When our data were inserted into Fox and Tylutki's model (1998), heat-induced reductions in DMI in both trials were only 4 to $2 \%$. This calculation indicates that, although the cows in our study were exposed to significant outdoor heat stress during a considerable portion of the day, a substantial part of the external heat load was mitigated by application of evaporative cooling.

Thus, it can be implied that when appropriate supplemental cooling is provided and/or there is sufficient time at a THI $<78$ for cows to recover partially from heat stress and when, simultaneously, DMI is not depressed, there is no need for an increase in dietary ingredient concentrations. In the current study, we further explored the possibility that cows may even benefit from a reduction in dietary $\mathrm{CP}$ concentration.

Table 5. Effect of dietary protein concentration on milk yield and composition.

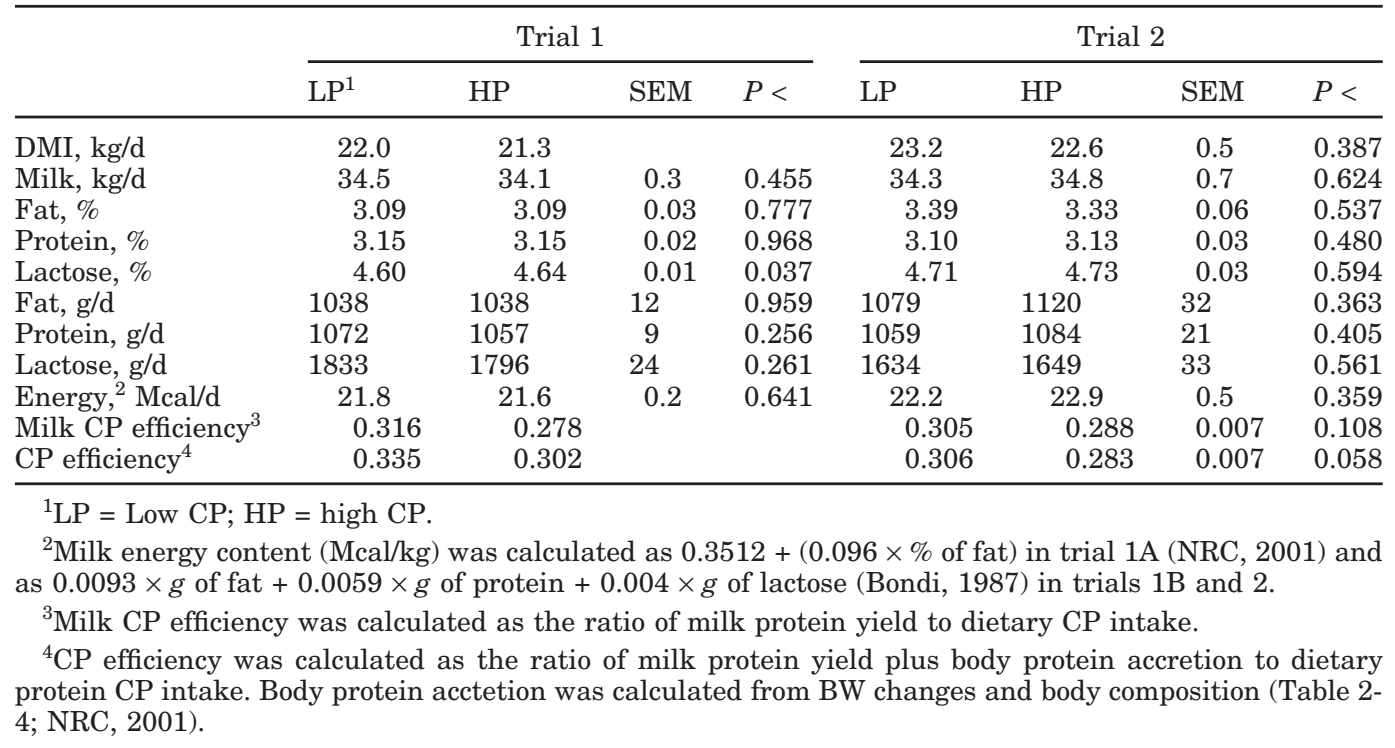




\section{Milk Yield Composition and Efficiency}

Yield of milk, components, and milk energy were similar for LP and HP diets in both trials (Table 5). Milk yield over the course of the trial was reduced by both treatments by 0.6 and $0.8 \mathrm{~kg} / \mathrm{wk}$ in trials 1 and 2 , respectively, and was not affected by treatment. In trial 1 , lactose concentration was higher in the HP diet. Concentration of milk fat and protein was unaffected by diet. Throughout the trials, in cows fed the LP and HP diets, lactose concentration was reduced by $0.10 \%$; concentration of fat was increased by 0.31 and $0.10 \%$ in trials 1 and 2 , respectively, and milk protein concentration was increased by 0.30 and $0.05 \%$ in trials 1 and 2 , respectively. The rate of change in milk constituents was not affected by treatment.

The calculated efficiency of milk protein production (expressed as g of milk CP/g of CP intake) appeared to increase from 0.28 in the HP diet to 0.32 in the LP diet in trial 1. Significance of this tendency could not be assessed in trial 1 because of group feeding. Similarly, in trial 2, the milk protein production efficiency tended to increase from 0.29 in the HP diet to 0.31 in the LP diet.

Overall, the finding in these trials that a 1.8 to $1.6 \%$ unit reduction in dietary $\mathrm{CP}$ concentration does not affect milk or milk protein production in cows consuming LP agrees with earlier reports concerning effects of dietary $\mathrm{CP}$ concentration on milk yield in mid lactation cows exposed to hot ambient temperatures (Higgin botham et al., 1989a,b; Taylor et al., 1991; Chen et al., 1993). Regression of protein efficiency (milk protein yield per CP intake) vs. dietary CP level (\% of DM) obtained from literature data resulted in the following equation: protein efficiency $=0.698( \pm 0.091)-0.0258$ $( \pm 0.0051) \times \mathrm{CP}(\%$ of dietary $\mathrm{DM})\left(R^{2}=0.678 ; \mathrm{n}=14\right.$; $P=0.003)$.

Our findings, that cows consuming diets of 15.3 or $17.0 \% \mathrm{CP}$ (with total CP intake of 3 to $4 \mathrm{~kg} / \mathrm{d}$ ) and producing approximately $35 \mathrm{~kg}$ of milk/d have respective efficiencies of milk CP production of 0.32 or 0.28 , are in the range described by the previously given equation. The changes in efficiency of $\mathrm{CP}$ production reported here are similar to efficiency trends found in cows that are not heat stressed and are fed a similar range of CP concentrations (Armentano et al., 1993; $\mathrm{Wu}$ and Satter, 2000). Protein utilization has been observed to decrease in heat-stressed growing lambs (Ames and Brink, 1977), apparently because of limited energy supply and usage of protein as an energy source. In contrast, feed efficiency was improved in growing pigs exposed to high ambient temperature when dietary $\mathrm{CP}$ level was reduced, although energy intake was ade-
Table 6. Effect of dietary protein concentration on plasma metabolite concentrations (trial 2).

\begin{tabular}{lccll}
\hline & LP $^{1}$ & HP & SEM & $P<$ \\
\hline Total protein, g/L & 8.3 & 8.2 & 0.1 & 0.211 \\
Albumin, g/L & 3.8 & 3.8 & 0.1 & 0.818 \\
NEFA, $\mu$ Eq/L & 136 & 133 & 4 & 0.590 \\
BHBA, mg/dL & 9.7 & 9.7 & 0.3 & 0.884 \\
Glucose, mg/dL & 57.8 & 58.0 & 0.8 & 0.876 \\
\hline
\end{tabular}

${ }^{1} \mathrm{LP}=$ Low $\mathrm{CP} ; \mathrm{HP}=$ high $\mathrm{CP}$.

quate (Le Bellego et al., 2002). The energy intake by the cows in the present study appeared also to be adequate.

The improved efficiency of milk protein synthesis in heat-stressed cows receiving low CP diets (described in the previous equation) was achieved mainly in diets containing relatively high RUP, compared with the recommended RUP concentration (38\% of $\mathrm{CP}$ or $6 \%$ of $\mathrm{DM}$ ) by the NRC (2001). The highest dietary RUP used in these studies were $59 \%$ of $\mathrm{CP}$ ( $11 \%$ of DM; Higgin botham et al., 1989a), $53 \%$ of CP (10\% of DM; Taylor et al., 1991), and $43 \%$ of CP (8\% of DM; Higginbotham et al., 1989b; Chen et al., 1993). The strategy behind such high RUP appeared to be a minimization of the energy costs associated with metabolic disposal of excess N (NRC, 2001). The shortcoming of surplus RDP is revealed by a literature data survey of DMI, RDP, and RUP concentrations for non-heat stress conditions, used to form a model of milk protein yield (NRC, 2001), demonstrating a quadratic response of milk protein yield to RDP concentration. It is worth noting that the milk protein yield in the current study was $13 \%$ lower than that of the NRC (2001) prediction, indicating a need to account also for ambient conditions when CP requirements are estimated.

The approach employed in the current study was to facilitate capture of surplus ruminal ammonia via an adequate supply of RDOM. The ratio of RDOM to RDP of about 5:1 used in the LP diets (Table 3) is considered adequate for satisfying energy requirements for microbial protein production (Arieli et al., 1993). That yield of milk and milk protein were unaffected by CP concentration whereas milk protein efficiency was higher in the LP diets, is consistent with the assumption that the supply of CP for LP groups was adequate, implying that cows fed the HP diet were fed a relative surplus of protein.

\section{Blood and Ruminal Metabolites}

Total protein and albumin concentration in plasma were similar between diets, averaging 8.3 and $3.8 \mathrm{~g} / \mathrm{dL}$ (trial 2; Table 6). These results further support the suggestion that cows fed the LP diet were supplied with 
Table 7. Effect of dietary protein concentration on rumen ammonia $\mathrm{N}$, plasma urea N (trial 1), and MUN (trial 2).

\begin{tabular}{lllll}
\hline & LP $^{1}$ & HP & SEM & $P<$ \\
\hline Rumen ammonia N, mg/dL & & & & \\
$\quad$ Before feeding & 14.3 & 16.0 & 0.5 & 0.007 \\
$\quad$ 3 h after feeding & 12.4 & 15.6 & 0.5 & 0.001 \\
$\quad \begin{array}{l}\text { Plasma urea N, mg/dL } \\
\quad \text { Before feeding }\end{array}$ & 15.0 & 15.2 & 0.3 & 0.615 \\
$\quad \begin{array}{l}\text { 3 h after feeding } \\
\text { Milk }\end{array}$ & 16.0 & 15.7 & 0.3 & 0.353 \\
$\quad$ Urea N, mg/dL & 14.8 & 16.1 & 0.5 & 0.001 \\
\hline
\end{tabular}

${ }^{1} \mathrm{LP}=$ Low $\mathrm{CP} ; \mathrm{HP}=$ high $\mathrm{CP}$.

adequate amounts of protein. Plasma albumin is an important source of available AA that can support AA needs when dietary supplies are limited (Moorby et al., 2002).

Blood concentration of glucose, NEFA, and BHBA were similar among treatments (averaging $58 \mathrm{mg} / \mathrm{dL}$, $134 \mu \mathrm{eq} / \mathrm{L}$, and $9.7 \mathrm{mg} / \mathrm{dL}$; trial 2; Table 6). Under conditions of negative energy balance, NEFA and BHBA concentrations in dairy cows tend to increase, whereas glucose concentrations decrease (Miettinen and Huhtanen, 1989). Threshold concentrations of 10 to $14 \mathrm{mg} / \mathrm{dL}$ of blood BHBA can be used to discriminate between healthy cows and cows with subclinical ketosis (Duffield et al., 1998). In heat-stressed cows, NEFA concentration tended to decrease, probably because of decreased mobilization of fatty acids during the heat exposure (Itoh et al., 1998). Although the cause for the relatively elevated ketone bodies concentration in our cows is unclear, it suggests precaution in using ketone bodies as a marker for evaluation of energy deficiency in heatstressed cows. Nevertheless, the similar metabolite concentrations in cows fed the LP and HP diets are in line with the finding that intake and OM digestibility were not adversely affected by the LP diet, suggesting that the dietary energy supply in these heat-stressed cows was adequate.

Volatile fatty acid concentrations in the rumen were measured only in trial 1 . Total VFA were similar among diets, averaging 83 and $99 \mathrm{mmol} / \mathrm{l}$ before feeding and $3 \mathrm{~h}$ post-feeding, respectively. Proportions of VFA were similar among diets and feeding time, averaging 620 , 250 , and $130 \mathrm{mmol} / \mathrm{mol}$ for acetate, propionate, and butyrate, respectively. The similarity of the VFA proportions is compatible with similar milk fat content in both diets.

Rumen ammonia $\mathrm{N}$ concentrations were significantly lower in the LP vs. HP diets (trial 1; Table 7). Before feeding and $3 \mathrm{~h}$ post-feeding, rumen ammonia $\mathrm{N}$ was 11 and $21 \%$ higher in the HP diet than in the LP diet, respectively. The higher ammonia level in cows fed the HP diet (Table 7) could have arisen from a higher rumi- nal deamination of protein, a higher rate of recycled urea, or both. Almost all of the protein in excess of dairy cows' requirements is excreted in the urine (Castillo et al., 2000). It has been suggested that supplying diets of heat-stressed dairy cows with protein levels greater than requirements can increase the amounts of water needed for urinary disposal of urea (Shalit et al., 1991). This extra demand may contrast with the increased water requirements for evaporative cooling of heatstressed cows (West, 1999). Plasma urea N concentrations were similar for cows fed LP and HP diets (trial 1 ; Table 7), whereas in trial 2 , milk $\mathrm{N}$ urea was $8 \%$ lower in cows fed the LP diet than in cows fed the HP dies (Table 7). Higginbotham et al. (1989a,b) reported a 28 to $35 \%$ decrease in plasma urea concentration by reducing dietary CP from 18.2 to $15.2 \%$ or from 18.5 to 16.1 in heat-stressed cows. The relatively low reduction of urea concentration in our experiments probably reflects lower difference in CP level between LP and $\mathrm{HP}$ diets.

The BCS of cows fed the LP diet increased $(P<0.05)$ more than that of cows fed the HP diet. Initial BW tended to be higher with the HP diet in trial 1, but final BW was similar among diets (Table 8). As a result, BW gain was higher $(P<0.03)$ in cows fed the LP diet by $100 \mathrm{~g} / \mathrm{d}$. Similarly, BW gain in trial 2 tended to be higher by $130 \mathrm{~g} / \mathrm{d}$ in cows fed the LP diet compared with that in cows fed the HP diet. That BW accretion in cows fed the LP diet was larger than that of their counterparts indicates that differences in overall protein efficiency between treatments were larger than the respective difference in milk protein efficiency. Accretion CP can be estimated from BW change and from body chemical composition. By using NRC (2001) body chemical composition values, adjusted for BCS data, the resulting overall $\mathrm{CP}$ efficiency in trial 2 was $8 \%$ higher for the LP diet than for the HP diet $(P<0.06$; Table 5).

Although the improved milk protein efficiency in LP diets has an obvious beneficial effect on reducing $\mathrm{N}$ dissipation to the environment (Wu and Satter, 2000) and on reducing feed costs (Godden et al., 2001), it may also be associated with an energetic advantage. As $1 \mathrm{~g}$ of excess intake of $\mathrm{N}$ is associated with an energy loss of $5.5 \mathrm{Kcal} / \mathrm{g}$ of $\mathrm{N}$ (Higginbotham et al., 1989b), a reduction of 300 to $400 \mathrm{~g}$ in intake protein in cows receiving the LP vs. HP diet is equivalent to about 260 to 350 kcal of energy saving caused by reduced deamination of AA in the LP diets. The findings of higher BW gain and higher BCS gain in cows fed the LP diet vs. the HP diet are compatible with energy saving caused by reduced metabolic cost of surplus $\mathrm{N}$ intake in the LP diets. Although endocrine status of mid to late lactation cows may shift the extra nutrients from the mammary gland to energy depots (Vernon, 1988), these extra en- 
Table 8. Effect of protein concentration on BCS and BW. ${ }^{1}$

\begin{tabular}{|c|c|c|c|c|c|c|c|c|}
\hline & \multicolumn{4}{|c|}{ Trial 1} & \multicolumn{4}{|c|}{ Trial 2} \\
\hline & $\mathrm{LP}^{2}$ & HP & SEM & $P<$ & LP & HP & SEM & $P<$ \\
\hline Initial BW, kg & 592.7 & 616.5 & 9.5 & 0.081 & 608.8 & 605.2 & 10.6 & 0.813 \\
\hline Final BW, kg & 633.3 & 648.3 & 10.1 & 0.300 & 610.0 & 595.5 & 11.9 & 0.396 \\
\hline $\mathrm{BW}$ gain, $\mathrm{kg}$ & 40.5 & 31.8 & 2.8 & 0.029 & 1.15 & -9.72 & 4.55 & 0.099 \\
\hline Initial BCS & 2.85 & 2.80 & 0.06 & 0.544 & 2.81 & 2.88 & 0.11 & 0.639 \\
\hline Final BCS & 3.09 & 2.90 & 0.07 & 0.049 & 2.976 & 2.929 & 0.100 & 0.748 \\
\hline Increase in BCS units & 0.237 & 0.101 & 0.049 & 0.052 & 0.167 & 0.048 & 0.050 & 0.092 \\
\hline
\end{tabular}

${ }^{1}$ Trial lasted for 80 to $90 \mathrm{~d}$.

${ }^{2} \mathrm{LP}=$ Low CP; HP = high CP.

ergy stores could be used to improve cows' body readiness for the next lactation cycle.

From the present study, we conclude that diets containing $15.3 \% \mathrm{CP}$, of which $35 \%$ is RUP (5.4\% of DM), and an appropriate ratio of RDOM to RDP may be adequate to maintain production in heat-exposed dairy cows kept under a forced evaporative cooling regimen and producing 29 to $38 \mathrm{~kg}$ of milk/d. This conclusion agrees with the NRC (2001) recommendation of $15.2 \%$ CP diets having 5.5\% RUP (dietary DM basis) for cows not under heat stress and producing $35 \mathrm{~kg} / \mathrm{d}$ of milk. Thus, it appears that there is no obvious need to increase the dietary CP (and RUP) concentration in heatstressed cow. In addition, diminishing environmental contamination, the energy saved by reducing the protein supply, may favor an improvement in body reserve accretion.

\section{ACKNOWLEDGMENTS}

The authors acknowledge financial support from the Israeli Dairy Board. We thank the dairy herd teams at kibbutz Kalia, kibbutz Ashdot Yaacov (Ikhud), and at the Volcani Center for their assistance in cow care and S. Zamwel for laboratory analyses.

\section{REFERENCES}

Ames, D. R., and D. R. Brink. 1977. Effect of temperature on lamb performance and protein efficiency ratio. J. Anim. Sci. 44:136140.

AOAC. 1995. Official Methods of Analysis of the Association of Official Analytical Chemists. 16th ed. AOAC, Arlington, VA.

Arieli, A., S. Mabjeesh, H. Tagari, I. Bruckental, and S. Zamwel. 1993. Evaluation of protein flow to the duodenum in dairy cattle by the in sacco method. Livest. Prod. Sci. 35:283-292.

Armentano, L. E., S. J. Bertics, and J. Riesterer. 1993. Lack of response to addition of degradable protein to a low protein diet fed to midlactation dairy cows. J. Dairy Sci. 76:3755-3762.

Barash, H., N. Silanikove, A. Shamay, and E. Ezra. 2001. Interrelationships among ambient temperature, day length, and milk yield in dairy cows under a Mediterranean climate. J. Dairy Sci. 84:2314-2320.

Bondi, A. A. 1987. Animal Nutrition. John Wiley \& Sons, Chichester, UK.

Castillo, A. R., E. Kebreab, D. E. Beever, and J. France. 2000. A review of efficiency of nitrogen utilisation in lactating dairy cows and its relationship with environmental pollution. J. Anim. Feed Sci. 9:1-32.

Chambers, A. B. 1970. A psychometric chart for physiological research. J. Appl. Physiol. 29:406-412.

Chaney, A. L., and E. P. Marbach. 1962. Modified reagent for determination of urea and ammonia. Clin. Chem. 8:130-132.

Chen, K. H., J. T. Hubert, C. B. Theurer, D. V. Armstrong, R. C. Wanderley, J. M. Simas, S. C. Chan, and J. L. Sullivan. 1993. Effect of protein quality and evaporative cooling on lactational performance of Holstein cows in hot weather. J. Dairy Sci. 76:819-825.

Cody, R. F., J. J. Murphy, and D. J. Morgan 1990. Effect of supplementary crude protein level and degradability in grass silage-based diets on performance of dairy cows, and digestibility and abomasal nitrogen flow in sheep. Anim. Prod. 51:235-244.

Coulomb, J. J., and L. Favereau. 1963. A simple semi-micro method for colorimetric determination of urea. Clin. Chem. 9:102-108.

Cummins, K. A. 1992. Effect of dietary acid detergent fiber on responses to high environmental temperature. J. Dairy Sci. 75:1465-1471.

Dijkstra, J., J. France, and D. R. Davies. 1998. Different mathematical approaches to estimating microbial protein supply in ruminants. J. Dairy Sci. 81:3370-3384.

Duffield, T. F., D. Sandals, K. E. Leslie, K. Lissemore, B. W. McBride, J. H. Lumsden, P. Efficacy of monensin for the prevention of subclinical ketosis in lactating dairy cows. J. Dairy Sci. 81:2866-2873.

Fox, D. G., and T. P. Tylutki. 1998. Accounting for the effects of environment on the nutrient requirements of dairy cattle. J. Dairy Sci. 81:3085-3095.

Godden, S. M., K. D. Lissemore, D. F. Kelton, K. E. Leslie, J. S. Walton, and J. H. Lumsden. 2001. Relationships between milk urea concentrations and nutritional management, production, and economic variables in Ontario dairy herds. J. Dairy Sci. 84:1128-1139.

Halachmi, I., Y. Edan, E. Maltz, U. M. Peiper, U. Moallem, and I. Brukental. 1998. A real-time control system for individual dairy cow food intake. Comp. Electron. Agric. 20:131-144.

Hassan, A., and J. D. Roussel. 1975. Effect of protein concentration in the diet on blood composition and productivity of lactating Holstein cows under thermal stress. J. Agric. Sci. (Camb.) 85:409-415.

Higginbotham, G. E., J. T. Huber, M. V. Wallentine, N. P. Johnston, and D. Andrus. 1989a. Influence of protein percentage and degrad ability on performance of lactating cows during moderate temperature. J. Dairy Sci. 72:1818-1823.

Higginbotham, G. E., M. Torabi, and J. T. Huber. 1989b. Influence of dietary protein concentration and degradability on performance of lactating cows during hot environmental temperatures. J. Dairy Sci. 72:2554-2564.

Itoh, F., Y. Obara, H. Fuse, M. T. Rose, I. Osaka, and H. Takahashi. 1998. Effect of heat exposure on plasma insulin, glucagon and metabolites in response to nutrient injection in heifers. Comp. Biochem. Physiol. 119C:157-164. 
Knapp, D. M., and R. R. Grummer. 1991. Responses of lactating dairy cows to fat supplementation during heat stress. J. Dairy Sci. 74:2573-2579.

Le Bellego L., J. van Milgen, and J. Noblet. 2002. Effect of high temperature and low-protein diets on the performance of growingfinishing pigs. J. Anim. Sci. 80:691-701.

Lippke, H., W. C. Ellis, and B. F. Jacobs. 1986. Recovery of indigestible fiber from feces of sheep and cattle on forage diets. J. Dairy Sci. 69:403-412.

Miettinen, H., and P. Huhtanen. 1989. The concentration of blood metabolites and the relations between blood parameters, fatty acid composition of milk and estimated ME-balance in dairy cows given grass silage ad libitum with five different carbohydrate supplements. Acta Agric. Scand. 39:319-330.

Moorby, J. M., R. J. Dewhurst, R. T. Evans, and W. J. Fisher. 2002. Effects of level of concentrate feeding during the second gestation of Holstein-Friesian dairy cows. 2. Nitrogen balance and plasma metabolites. J. Dairy Sci. 85:178-189.

Nianogo, A. J., H. E. Amos, M. A. Froetschel, and C. M. Keery. 1991. Dietary fat, protein degradability, and calving season: effects on nutrient use and performance of early lactating cows. J. Dairy Sci. 74:2243-2255.

NRC. 1981. Effect of Environment on Nutrient Requirements of Domestic Animals. National Academic Press, Washington, DC.

NRC. 2001. Nutrient Requirements of Dairy Cattle. 7th rev. Natl. Acad. Sci., Washington, DC.

Orskov, E. R., and I. McDonald. 1979. The estimation of protein degradability in the rumen from incubation measurements weighted according to rate of passage. J. Agric. Sci. (Camb.) 92:499-503.

Rodriguez, L. A., C. C. Stallings, J. H. Herbein, and M. L. McGilliard. 1997. Effect of degradability of dietary protein and fat on ruminal, blood, and milk components of Jersey and Holstein cows. J. Dairy Sci. 80:353-363.

SAS User's Guide: Statistics, Release 8.2. 2001. SAS Inst., Inc., Cary, NC.

Shalit, U., E. Maltz, N. Silanikove, and A. Berman. 1991. Water, sodium, potassium, and chlorine metabolism of dairy cows at the onset of lactation in hot weather. J. Dairy Sci. 74:1874-1883.

Skaar, T. C., R. R. Grummer, M. R. Dentine, and R. H. Stauffacher. 1989. Seasonal effects of prepartum and postpartum fat and niacin feeding on lactation performance and lipid metabolism. J. Dairy Sci. 72:2028-2038.

Taylor, R. B., J. T. Huber, R. A. Gomez-Alarcon, F. Wiersma, and X. Pang. 1991. Influence of protein degradability and evaporative cooling on performance of dairy cows during hot environmental temperatures. J. Dairy Sci. 74:243-249.

Van Soest, P. J., J. B. Robertson, and B. A. Lewis. 1991. Methods for dietary fiber, neutral detergent fiber, and nonstarch polysaccharides in relation to animal nutrition. J. Dairy Sci. 74:35833597.

Vernon, R. G. 1988. The partitioning of nutrients during the lactation cycle. Pages 32-52 in Nutrition and Lactation in the Dairy Cows. P. C. Garnsworthy, ed. Butterworths, London, UK.

Weigel, D. J., J. P. Elliot, and J. H. Clark. 1997. Effect of amount and ruminal degradability of protein on nutrient digestibility and production by cows fed tallow. J. Dairy Sci. 80:1150-1159.

West, J. W. 1999. Nutritional strategies for managing the heatstressed dairy cow. J. Anim. Sci. 82:S21-S35.

Wildman, E. E., G. M. Jones, P. E. Wagner, R. L. Bowman, H. F Troutt, and T. N. Sesch. 1982. A dairy cow body condition scoring system and its relationship to selected production characteristics. J. Dairy Sci. 65:495-501.

Wu, Z., and L. D. Satter. 2000. Milk production during the complete lactation of dairy cows fed diets containing different amounts of protein. J. Dairy Sci. 83:1042-1051. 